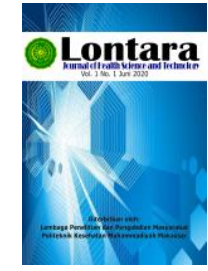

Lontara

Journal of Health Science and Technology

http://jurnal.poltekkesmu.online/lontarariset

Vol 2, No. 1, Juni 2021, pp 35-41

p-ISSN:0000-0000 dan e-ISSN: 2721-6179

DOI: https://doi.org/

\title{
IDENTIFIKASI SENYAWA TANIN PADA EKSTRAK SABUT BUAH PINANG (Areca catechu. L)
}

\author{
Waode Rustiah, A. Fatmawati, Dewi Arisanti, Alfian
}

Program Studi Teknologi Laboratorium Medis, Politeknik Kesehatan Muhammadiyah Makassar

Email: waoderustiah79@gmail.com

\section{Artikel info}

\section{Artikel history:}

Received;03-03-2021

Revised:22-05-2021

Accepted;24-05-2021

Keyword:

Tannins, Areca Fruit Coir Extract.

Kata Kunci:

Tanin, Ekstrak Sabut Buah Pinang.
Abstract. Areca catechu (Areca catechu. L) contains many chemical components, namely, pectin, cellulose, hemicellulose, lignin, pectin oxalate and flavonoids. Tannins are very complex organic substances and consist of phenolic compounds. Tannins are obtained by extraction with water and ethanol solvents because tannins can dissolve with these solvents. This study aims to identify tannin compounds in areca nut using ethanol as a solvent. This research is a laboratory experiment with an extraction process using the maceration method. The areca nut is dried and mashed and then sifted. Then the powder was macerated with $70 \%$ ethanol solvent for \pm 24 hours, then evaporated and then tested qualitatively and determined the type of tannins. The results showed that areca nut extract was positive for tannins and the type of tannin was condensed tannins.

Abstrak. Sabut buah pinang (Areca catechu. L) mengandung banyak komponen senyawa kimia diantaranya pektin, selulosa, hemiselulosa, lignin, pectin oksalat dan flavonoid. Tanin merupakan jenis senyawa organik sangat kompleks, sehingga termasuk ke dalam golongan polifenol. Dalam memperoleh senyawa tannin ini, dilakukan dengan mengekstraksi menggunakan pelarut. Umumnya pelarut yang digunakan adalah air dan etanol karena diketahui senyawa tanin ini mampu larut dengan kedua pelarut termaksud. Adapun tujuan penelitian ini dilakukan untuk mengidentifikasi senyawa tanin yang terdapat dalam sabut buah pinang menggunakan pelarut etanol. Eksperimen laboratorik melalui proses ekstraksi dalam mengidentifikasi senyawa tanin ini yaitu dengan menggunakan metode maserasi. Sabut buah pinang yang sudah kering dihaluskan terlebih dahulu, lalu dilakukan pengayakan. Selanjutnya serbuk direndam dalam larutan etanol $70 \%$ selama \pm 24 jam, kemudian dievaporasi, dan dilakukan uji kualitatif dan penetapan jenis tanin. Dari hasil penelitian, didapatkan bahwa ekstrak sabut buah pinang positif mengandung tanin dan jenis taninnya yaitu tanin terkondensasi. 
Coresponden author:

Email: waoderustiah79@gmail.com

artikel dengan akses terbuka dibawah lisensi CC BY -4.0

\section{PENDAHULUAN}

Buah pinang (Areca catechu. L) termasuk jenis tumbuhan palmae, dimana family Arecaceae ini memiliki tinggi yang mencapai 12 hingga $30 \mathrm{~m}$, memiliki akar serabut putih, batang tegak lurus. Pembentukan batang akan nampak setelah berumur lebih dari 2 tahun dan akan berbuah pada umur 5-8 tahun, hal ini tentu saja bergantung pada keadaan tanah dengan kelembaban cukup dan berada pada rentang $\mathrm{pH} 5-8$, hal ini sangat mendukung untuk pertumbuhan pinang. Jenis tumbuhan ini banyak tersebar di Afrika, Arab, Tropikal Asia dan Papua New Guinea (Sihombing, 2000). Terkhusus di negara Indonesia, buah pinang ini banyak tersebar mulai dari daerah Aceh hingga ke Papua (Staples \& Bevacqua., 2006).

Pinang (Areca catechu. L) jenis palmae hingga saat ini, masih kurang mendapatkan perhatian serius, dibandingkan tumbuhan palmae yang lainnya. Umumnya tumbuhan ini tumbuh melalui proses alami dan meskipun tumbuhan ini sengaja ditanam, akan tetapi fungsinya hanya sebagai pembatas daerah perkebunan. Ini dikarenakan pemanfaatan tanaman pinang ini yang masih sangat terbatas, contohnya bijian buah pinang hanya dikonsumsi bersama sirih dan keperluan acara adat pada daerah tersebut. Buah pinang banyak dimanfaatkan oleh penduduk setempat dan sudah tradisi secara turun temurun, dan apabila dalam sehari mereka tidak mengkonsumsi buah pinang, maka kondisi tubuh yang akan dirasakan terasa lemah. Bahkan menurut warga, disaat mereka lagi bersantai, rasanya tidak lengkap tanpa mengunyah pinang (Nofriadi., 2009).

Oleh sebagian masyarakat Indonesia, kebiasaan mengomsumsi buah pinang (Areca catechu. L) telah dilakukan sejak lama. Bahkan suku Kaimana (Papua Barat) percaya dengan mengunyah pinang dapat memperkuat gigi dan membuat tubuh semakin berstamina. Kebiasaan mengunyah pinang dengan campuran sirih dan kapur hingga menjadi penyebab warna merah yang melekat pada gigi dan mulut, hampir setiap hari mereka lakukan meskipun sedang bekerja atau lagi santai (Arisandi, 2008). Selain itu, ekstrak buah pinang sangat berperan sebagai antiseptik pada obat kumur, dikarenakan efektivitas dari ekstrak yang dihasilkan terhadap perkembangan pertumbuhan bakteri, mampu menjadi zona hambat lebih besar dibandingkan dengan ketiga jenis obat kumur yang dikomersialkan (Yulineri, dkk, 2005).

Umumnya, bagian buah pinang yang paling sering dikonsumsi oleh sebagian masyarakat Indonesia adalah biji dan sabut buah yang muda. Selain itu, diketahui bahwa sabut buah pinang juga dapat digunakan sebagai pembuat papan dan bahan kain. Secara tradisional, kegunaan lainnya yaitu 
untuk mengatasi gangguan pada saluran pencernaan (dyspepsia), edema, sembelit dan beri-beri (Dalimartha. 2009). Diketahui pula bahwa, biji buah pinang mengandung beberapa senyawa kimia yaitu tanin, alkaloid, flavan, dan lignin. Sedangkan kandungan sabut buah pinang antara lain: flavonoid, alkaloid, pektin, pektin oksalat, hemiselulosa, dan selulosa. Dengan terdapatnya kandungan senyawa lain seperti pektin dan flavonoid, hal ini membuat sabut buah pinang juga membantu dalam mengobati diare. Kandungan flavonoid yang terdapat pada sabut buah pinang, bekerja dengan menghambat motilitas usus dan terjadinya pelepasan asetilkolin pada saluran pencernaan, sedangkan di dalam usus, pectin juga aktif bekerja sebagai adsorben (Djoko, et.al., 2013).

Salah satu jenis senyawa yang termasuk ke dalam golongan polifenol adalah tanin. Umumnya pada tumbuh-tumbuhan banyak ditemukan senyawa tanin. Tanin banyak terdapat dalam daun, biji dan buah pada tumbuhan (Harborne, 1987). Senyawa organik terdiri dari campuran senyawa polifenol kompleks, dibangun dari unsur-unsur $\mathrm{C}, \mathrm{H}$, dan $\mathrm{O}$ serta membentuk molekul besar dengan berat molekul lebih besar dari 2000 merupakan senyawa tanin. Dahulu dalam menyamakkan kulit hewan digunakan tannin, karena sifat dari tanin yang dapat mengikat protein. Selain itu juga dapat mengikat senyawa alkaloid dan gelatin. Penelitian "Analisis Kadar Tanin Ekstrak Air dan Ekstrak Etanol pada Biji Pinang Sirih (Areca catechu. L)" dilakukan analisis kualitatif dan penetapan kandungan tanin. Hasil penelitian yang sudah dipublikasikan diperoleh kadar tanin menggunakan pelarut air sebanyak $6,45 \%$, sedangkan yang menggunakan pelarut etanol 96\% diperoleh sebanyak 8,53\% dengan masingmasing menggunakan 50 gram sampel. Hasil penelitian ini dilakukan dengan cara ekstraksi tanin dari biji buah pinang sirih menggunakan pelarut etanol, yaitu menghasilkan kadar tanin yang lebih tinggi dari cara ekstraksi menggunakan pelarut air(Sulastry, 2009). Selain itu, penelitian lain menyebutkan bahwa buah pinang juga banyak mengandung proantosiadinin, merupakan suatu tanin terkondensasi yang termasuk dalam golongan flavonoid. Diketahui pula bahwa proantosianidin ternyata memiliki 7 efek terhadap antibakteri, antivirus, antikarsinogenik, anti-inflamasi, anti-alergi, dan vasodilatasi (Nonaka, 1989).

Sejauh ini belum ada penelitian identifikasi senyawa tanin pada sabut buah pinang. Dari beberapa uraian di atas, maka perlu diadakan penelitian mengenai identifikasi senyawa tanin pada sabut buah pinang (Areca catechu. L). Adapun tujuan penelitian ini adalah untuk mengidentifikasi senyawa tannin pada sabut buah pinang (Areca catechu. L) dan penetapan jenis tanin.

\section{BAHAN DAN METODE}

\section{Bahan}

Sabut buah pinang, kertas saring whatman no. 42 aquades, etanol 70\%, $\mathrm{NaCl} 10 \%, \mathrm{FeCl} 3$, dan gelatin. 
Alat

Neraca analitik, pengayak ukuran 30 mesh, pipet tetes, corong, kertas saring, pisau, gelas kimia, rotary evaporator, dan tabung reaksi.

\section{Prosedur Kerja}

\section{Penyiapan Bahan}

Buah pinang yang muda sebanyak 40 buah dikupas dan diambil sabutnya sebanyak \pm 400 gram. Sabut tersebut dibersihkan, kemudian dikeringkan di dalam oven dengan suhu berkisar 30-50 oC untuk menghilangkan kadar airnya. Setelah sabut buah pinang kering, selanjutnya dihaluskan dengan blender dan diayak menggunakan pengayak ukuran 30 mesh agar terbentuk serbuk yang lebih halus dan seragam

\section{Pembuatan Ekstrak Etanol 70\% sabut buah pinang}

Sebanyak 100 gram serbuk sabut buah pinang direndam dengan pelarut etanol $70 \%$ selama \pm 24 jam dan selanjutnya disaring menggunakan kertas saring whatman. Kemudian dilanjutkan dengan penguapan pelarut etanol 70\% menggunakan Rotary Evaporator hingga diperoleh ekstrak kental, untuk selanjutnya disebut dengan ekstrak sabut buah pinang $70 \%$.

\section{Analisis Kualitatif}

Hasil ekstrak etanol 70\% sabut buah pinang yang didapatkan, maka selanjutnya dilakukan uji sebagai berikut, sebanyak $5 \mathrm{ml}$ ekstrak dipipet, lalu dimasukkan ke dalam tabung reaksi. Setelah itu, menambahkan 5 tetes $\mathrm{NaCl}$ 10\%, selanjutnya dilakukan penyaringan apabila terbentuk endapan. Lalu filtratnya diambil dan dibagi menjadi 2 bagian, bagian A, dan B. Adapun perlakuan ke 2 filtrat secara berbeda, dimana filtrat A ditambahkan larutan gelatin, kemudian diamati perubahan yang terjadi. Jika terbentuk endapan di dasar tabung reaksi, berarti mengandung tannin. Sedangkan ke dalam filtrat B di tambahkan 3 tetes pereaksi $\mathrm{FeCl} 3$. Jika dalam tabung reaksi terbentuk warna hijau kehitaman, hal ini menunjukkan bahwa terdapat tanin terhidrolisis. Sedangkan apabila warna hijau kecoklatan terbentuk, maka hal tersebut merupakan senyawa tanin terkondensasi.

\section{HASIL PENELITIAN}

Berdasarkan hasil penelitian di Balai Besar Laboratorium Kesehatan Makassar (BBLK) tentang Identifikasi Senyawa Tanin pada Ekstrak Sabut Buah Pinang (Areca catechu. L). Hasil yang diperoleh dapat dilihat pada tabel 1.1 di bawah ini :

Tabel 1.1. Hasil Identifikasi Senyawa Tanin pada Ekstrak Sabut Buah Pinang (Areca catechu. L)

\begin{tabular}{llll}
\hline No & Pengujian & Hasil & Keterangan \\
\hline 1 & Gelatin & Terbentuk Endapan & $(+)$ Mengandung Tanin \\
\hline 2 & $\mathrm{FeCl}_{3}$ & Terbentuk Warna Hijau Kecoklatan & $\begin{array}{l}(+) \text { Positif Mengandung Tanin } \\
\text { Terkondensasi }\end{array}$ \\
\hline
\end{tabular}

Sumber: Data primer 
Keterangan :

1. Pengujian gelatin untuk mengidentifikasi senyawa tanin dalam sampel sabut buah pinang

2. Pengujian $\mathrm{FeCl} 3$ untuk penentuan jenis tanin dalam sampel sabut buah pinang

\section{PEMBAHASAN}

Pada penelitian sebelumnya telah dilakukan uji kualitatif dan penetapan kadar tanin hasil ekstrak menggunakan pelarut air dan pelarut etanol pada biji pinang sirih (Areca catechu. L) (Sulastry, 2009). Pada penelitian ini, kami menggunakana bagian lain dari buah pinang yaitu sabut buah pinang yang masih muda.

Langkah awal yang dilakukan untuk penelitian ini yaitu terlebih dahulu menyiapkan alat dan bahan yang akan digunakan. Sampel dipilih dari buah pinang yang masih muda yang diambil dari Kabupaten Kaimana, Papua Barat. Selanjutnya buah pinang dipisahkan dari kulitnya dan diambil sabutnya lalu dilakukan pengeringan di bawah sinar matahari langsung, lalu dilanjutkan dengan pemanasan dalam oven pada suhu $80^{\circ} \mathrm{C}$ agar jumlah kandungan air dalam sampel sudah tidak ada lagi, karena kandungan air dalam suatu sampel kemungkinan akan mempengaruhi hasil penelitian. Setelah sampel kering, dihaluskan menggunakan blender lalu diayak dengan pengayak ukuran 30 mesh untuk mendapatkan serbuk yang seragam.

Melalui proses ekstraksi, senyawa tanin dapat dipisahkan dari senyawa-senyawa kimia lain yang terdapat dalam sabut buah pinang (Khumaidah, dkk, 2019). Pembuatan ekstrak etanol $70 \%$ sabut buah pinang (Areca catechu. L) dilakukan dengan metode perendaman sampel dengan pelarut organik (maserasi) yang digunakan pada temperature ruangan disebut ekstraksi cara dingin, hal ini dilakukan dalam upaya mendapatkan ekstrak dan sebisa mungkin dihindari adanya penggunaan pemanasan, karena dikhawatirkan senyawa yang terdapat dalam sabut buah pinang yang muda bisa rusak apabila dilakukan pemanasan pada suhu tinggi. Dalam isolasi senyawa bahan alam, teknik maserasi sangat menguntungkan karena dengan perendaman, pada sampel tumbuhan akan terjadi pemecahan dinding dan membrane sel yang terjadi akibat perbedaan tekanan antara di dalam dan di luar, sehingga metabolik sekunder yang terdapat di dalam senyawa tersebut akan terlarut dalam pelarut organik dan hasil dari ekstraksi senyawa akan sempurna. Hal ini karena proses perendaman dapat diatur waktu lama perendaman (Nonaka, 1989).

Selanjutnya serbuk kering sabut buah pinang direndam, lalu dilakukan dengan penambahan pelarut etanol $70 \%$, kemudian didiamkan selama \pm 24 jam dan disaring menggunakan kertas saring Whatman no. 42 sehingga didapat filtratnya. Filtrat yang didapat, lalu dipekatkan dengan Rotary evaporator pada suhu $75^{\circ} \mathrm{C}$ agar senyawa yang terdapat dalam ekstrak sabut buah pinang tidak ikut menguap. Dari proses ekstraksi didapatkan ekstrak sebanyak $7 \mathrm{ml}$, dengan ekstrak kental berwarna coklat.

Hasil ekstraksi kemudian diidentifikasi kandungan senyawa tanin dan ditentukan jenis taninnya menggunakan pereaksi gelatin dan $\mathrm{FeCl}$. Dalam penelitian ini, dilakukan identifikasi 
senyawa tanin dengan menambahkan larutan $\mathrm{NaCl} 10 \%$ sebanyak 5 tetes ke dalam $5 \mathrm{ml}$ larutan ekstrak, dengan tujuan untuk mengendapkan zat-zat lain yang bukan tanin. Kemudian selanjutnya dilakukan penyaringan dengan kertas saring Whatman dan diambil filtratnya. Lalu filtratnya dibagi menjadi 2 bagian yaitu bagian A dan B.

Filtrat A diuji dengan pereaksi gelatin untuk mengetahui adanya senyawa tanin. Apabila terbentuk endapan setelah ditambahkan pereaksi gelatin, hal ini menunjukkan bahwa pada ekstrak sabut buah pinang positif mengandung senyawa tanin. Semua tanin akan menimbulkan endapan baik dalam jumlah sedikit atau banyak, jika ditambahkan dengan gelatin (Mosier, dkk., 2005). Hal ini karena gelatin merupakan protein alami yang memberikan sifat pengstabil dan pengental bagi media. Sehingga terbentuk endapan karena sifat tanin yaitu dapat mengikat protein.

Filtrat $\mathrm{B}$ diuji dengan pereaksi $\mathrm{FeCl} 3$ untuk menentukan jenis tanin. Penggunaan $\mathrm{FeCl} 3$ untuk ekstrak sabut buah pinang menunjukkan terjadinya perubahan warna menjadi hijau kecoklatan, hal ini menandakan bahwa ekstrak sabut buah pinang mengandung jenis tanin terkondensasi. Terjadinya pembentukan warna hijau kecoklatan ini karena terbentuknya senyawa kompleks antara logam Fe dan tanin. Senyawa kompleks terbentuk karena adanya ikatan kovalen koordinasi antara ion atau atom logam dengan atom non logam (Hermiati, dkk., 2005).

Tanin termasuk ke dalam golongan polifenol dan memiliki aktivitas antibakteri. Mekanisme yang diperkirakan terjadi adalah efek toksisitas tanin terhadap ion logam dimana dapat menambah daya toksisitas tanin. Biasanya tanin terkondensasi tidak dapat dihidrolisis, melainkan terkondensasi yang mana menghasilkan asam klorida $(\mathrm{HCl})$. Kebanyakan tanin terkondensasi terdiri dari polimer flavonoid, dimana tanin jenis ini dikenal dengan nama Proanthocyanidin yang merupakan polimer dari flavonoid dan dihubungkan melalui $\mathrm{C} 8$ dengan $\mathrm{C} 4$, contohnya Sorghum procyanidin yang tersusun dari catechin dan epiccatechin (Staples \& Bevacqua., 2006).

\section{KESIMPULAN}

Berdasarkan hasil penelitian di Balai Besar Laboratorium Kesehatan (BBLK) Makassar pada sampel sabut buah pinang (Areca catechu. L) dari Kabupaten Kaimana telah dilakukan, dan disimpulkan bahwa sabut buah pinang dari Kabupaten Kaimana mengandung senyawa tanin dan mengandung jenis tanin terkondensasi.

\section{UCAPAN TERIMA KASIH}

Ucapan terima kasih untuk semua pihak yang sudah banyak membantu penelitian ini hingga dapat terlaksana dengan baik.

\section{DAFTAR PUSTAKA}

Arisandi, 2008. Khasiat Tanaman Obat. Pustaka Buku Murah. Jakarta.

Dalimartha. 2009. Atlas Tumbuhan Obat Indonesia Jilid 1. Jakarta: Trubus Agriwidya. 
Departemen Kesehatan dan Kesejahteraan Sosial, 2001. Inventaris Tanaman Obat Indonesia 1. Jilid 2. Bakti Husada. Jakarta.

Depkes RI, 1989. Materia Medika Indonesia. Jilid V. Jakarta.

Ditjen POM, 1995. Farmakope Indonesia Edisi IV. Jakarta: Departemen Kesehatan RI.

Ditjen POM, 2000. Parameter Standar Umum Ekstrak Tumbuhan Obat. Cetakan Pertama. Jakarta: Departemen Kesehatan RI.

Hargono, Djoko et al., 2013. Materia Medika Indonesia Jilid VI. Ditjen POM. Jakarta.

Harborne, J.B., 1987. Metode Fitokimia. Cetakan 2. Institut Pertanian Bandung.

Hermiati, dkk,. 2005. Pemanfaatan Biomassa Lignolselulosa Ampas Tebu untuk Produksi Bioetanol. Fakultas Teknologi Pertanian. Institut Pertanian Bogor.

Mosier, dkk,. 2005. Features of Promising Technologies for Pretreatment of Lignocellulosic Biomass. Biore Sourse Technology.

Nika Khumaidah, dkk, 2019. Inhibisi Korosi Ekstrak Buah Pinang (Areca Catechu L.) sebagai Penghambat Laju Korosi pada Baja Karbon Rendah C-Mn Steel dengan Medium Korosif $\mathrm{HCl}$ dan NaCl. Jurnal Teori dan Aplikasi Fisika, Vol 07, No. 01.

Nofriadi., 2009. Keragaman Nilai Lignin Terlarut Asam (Acid Soluble Lignin) dalam Kayu Reaksi Pinus Merkussi Jungh Et de Vriese dan Gnetum gnemon Linn. Fakultas Kehutanan. Institut Pertanian Bogor.

Nonaka, G, 1989. Isolation and Structure Elucidation of Tannins. DOI: 10.1351/PAC198961030357.

Sihombing, 2000. Budidaya Tanaman Pinang. Jakarta: Penebar Swadaya.

Staples \& Bevacqua., 2006. Areca catechu. L (Betel Nut Palm). Species Profile for Pacific Island Agroforestry. Diakses 3 Maret 2019.

Sulastry, Tati., 2009. "Analisis Kadar Tanin Ekstrak Air dan Etanol Pada Biji Pinang Sirih (Areca catechu. L). Jurnal Cemica Vol 10. UNM.

Titin Yulineri, dkk, 2005. Selenium dari Ekstrak Biji dan Akar Pinang (Areca Catechu L.) yang Difermentasi dengan Konsorsium Acetobacter-Saccharomyces sebagai Antiseptik Obat Kumur. Jurnal Biodiversitas, Vol 7, No. 1. Hal 18-20. DOI: 10.13057/biodiv/d070106.

Tiwow., 2013. Uji Efek Antielmintik Ekstrak Etanol Biji Pinang (Areca catechu. L) terhadap Cacing Ascaris Lumbricoides dan Ascaridia Galii secara In Vitro. Pharmacon Jurnal Ilmiah Farmasi UNSRAT. 